ISSN $0258-7122$

Bangladesh J. Agril. Res. 32(3) : 335-347, September 2007

\title{
IMPACTS OF PARTICIPATORY VARIETY SELECTION IN WHEAT ON AGRO-ECONOMIC CHANGES OF WHEAT FARMERS IN BANGLADESH
}

\author{
D.B. PANDIT ${ }^{1}$, M. E. BAKSH ${ }^{2}$, M. A. SUfIAN ${ }^{3}$ \\ M. HARUN-UR-RASHID ${ }^{4}$ AND M. M. IsLAM ${ }^{5}$
}

\begin{abstract}
Impacts of participatory variety selection in wheat on agro-economic changes like adoption of new wheat varieties and production technologies, income and attitude change of the wheat farmers, etc. are presented in the paper. Participatory variety selection was conducted at 12 villages of four districts in Bangladesh. Base line information from the villages was collected through participatory rural appraisal and household survey in 2002. Data on agroeconomic changes were collected through household survey in 2005. Impacts were assessed from the difference of the data of two surveys. The area of the check variety Kanchan came down from $97.8 \%$ (covered in 2002) to $57 \%$ in the working villages in 2005 . Varietal diversity was increased remarkably and seven varieties were found to cultivate in 2004-05. The new varieties occupied $43 \%$ of the wheat areas. Seed preservation by farmers was increased remarkably and 208 tons seeds of new vrieties were preserved by them in 2004-05. When $60 \%$ seeds of their total requirements were collected from Bangladesh Agricultural Development Coporation in 2002, then, $100 \%$ seeds were used from farmers' own source in 2004-05. There were remarkable changes in production technology adoption, sources of agricultural knowledge, attitude and income changes. Farmers' income was increased to Tk. 11148/ha due to cultivation of new varieties and use of recommended production technologies. Participatory variety selection approach in wheat was found very useful to increase wheat production in the working villages. Widespread use of this approach may be useful throughout the county in other crops also.
\end{abstract}

Key Words: Wheat, participatory variety selection (PVS), impact, income change, attitude change, varietal diversity.

\section{Introduction}

Wheat is the $2^{\text {nd }}$ important cereal crop in Bangladesh. Its production in 2006 was around 1 million metric tons but requirement is 3.0-3.51 million metric tons, and consumption is increasing @3\% per year (Sufian, 2005). Wheat yield and production in the country have been decreasing mainly due to wide spread cultivation of disease susceptible Kanchan variety (Sufian, 2005) and inadequate

${ }^{1-5}$ Wheat Research Centre, BARI, Nashipur, Dinajpur, Bangladesh. 
adoption of recommended management technologies. Cultivation of a single variety in large areas is also potentially danagerous in the view of disease epidemic, even if, the variety is tolerant to the pathogens of existing diseases. Varietal diversity is advisable to address varied phsical environments, socioeconomic conditions and farmers' needs. To reduce import cot, increase in production in the country is very important. Wheat Research Centre (WRC), Bangladesh Agricultural Research Institute (BARI) has released 24 varieties through conventional breeding approach. Varieties developed in this approach are usually not widely adapted, and that may be one of the reasons for low adoption. Though, the country is small, still there is some microclimatic difference that demands specific adapted varieties.

So, participatory variety selection (PVS) research was started at the WRC, BARI, Bangladesh in 2002 to overcome constraints that cause farmers' to grow old varieties (Joshi and Witcombe, 1996; Witcombe et al., 1996). Farmers possess the ability and knowledge for selecting crops varieties suitable to their environments, resources, quality and other consumer requirements. Research cost can be reduced and adoption rates increased if the farmers are allowed to participate in variety testing and selection process (Joshi et al., 1995). Participatory research also increases farmers' knowledge that enables them to retain seeds effectively from year to year (Grisley and Shamambo, 1993) and refrain from buying seeds by the poor farmers each year (Spearling and Loevinsohn, 1993).

Impacts of participatory variety selection have been studied in many countries (Joshi et al., 1995; Joshi and Witcombe, 1996; et al., 1996). Impact assessment is very important for future policy decision, but it was not done before in Bangladesh.

In this paper, adoption of farmers-selected varieties and management technologies, seed preservation, and most importantly the changes in incomes and attitudes of the farmers' due to PVS have been discussed.

\section{Methods \\ Experimental sites}

The PVS researches were conducted at 12 villaes of greater Dinajpur, Jessore, Rajshahi, and Jamalpur districts of Bangladesh (Table 1). Most of the wheat of the country is grown in these districts. Each site has particular target population environments (TPE). The soils of Dinajpur is acidic ( $\mathrm{pH}$ ranges from 4.5 to 5.0), poor in fertility with micronutrient deficiency and sometimes foggy weather from last week of January intermittently prevails $>15$ days that limits sunlight during 
anthesis to grain filling stages of the crop and enhance spikelets sterility. The climate of Jessore is hot and humid as a result, Bipolaris leaf blight (BpLB) disease is the major problem in the district. This area also needs terminal heat tolerant variety. Rajshahi is a low rainfall dry area and irrigation facilities are not adequate. The wheat of greater Jamalpur is mainly grown in char (river bank) areas. The soil is sandy and irrigation facilities are not adequate.

\section{Participatory rural appraisal (PRA)}

Participatory rural appraisal (PRA) was conducted at four selected villages from four districts in 2002. A 12-member team was formed with scientists from different disciplines, extension, and NGO personnel headed by an Economist. This team together with randomly selected 25 farmers, irrespective of wealth, caste, and sex (where available) conducted PRA in each village to collect base line information about agro-economic situations of the farmers. Base line information from other eight villages (Table 1) on agro-economic conditions of the farmers was collected through house hold level survey from 30 farmers per village by the PVS team.

\section{Impact assessment}

Impact assessment was done in 2005 by a team of researchers, extension, and NGO personnel headed by a $3^{\text {rd }}$ person (an Economist) who was not involved with the PVS activity. Impact assessment data were collected from 30 farmers from each of the 12 villages by the team members. The criteria for selecting 30 farmers were as follows:

1. ten farmers were from PVS research collaborators;

2. ten farmers were not PVS research collaborators but got training/demonstration on wheat;

3. the rest 10 farmers were new to the researchers and did not get any training/demonstration.

Out of those 30 farmers, 5-8 were female (at Dinajpur site only). The farmers were randomly selected irrespective of wealth, religion, and sex. A house hold level questionnaire (HLQ) was prepared to record data emphasizing on new variety and production technology adoption, varietal diversity change, seed production and preservation, sources of agricultural knowledge, income and attitude change, women empowerment in agriculture, etc. The questionnaire was filled-up by the members of the team separately. 
Table 1. List of selected villages for PVS research, base line information and impact assessment in different districts of Bangladesh.

\begin{tabular}{ll|c|c}
\hline $\begin{array}{c}\text { Greater } \\
\text { District }\end{array}$ & \multicolumn{1}{c|}{ Name of the village } & $\begin{array}{c}\text { Base line } \\
\text { information } \\
\text { collected in 2002 } \\
\text { by }\end{array}$ & $\begin{array}{c}\text { Impact } \\
\text { assessment } \\
\text { survey } \\
\text { conducted in } \\
\text { 2005 by }\end{array}$ \\
\hline \multirow{3}{*}{ Dinajpur } & Village:Daulatpur, Upazila: Thakurgaon & PRA & HLQ \\
& Village: Jogdal, Upazila: Birgonj & HLQ & HLQ \\
& Village: Hatiari, Upazila: Kaharol & HLq & HLQ \\
\hline \multirow{3}{*}{ Jessore } & Village: Bhalukgarh Upazila: Keshabpur & PRA & HLQ \\
& Village: Jalalpur, Upazila: Monirampur & HLQ & HLQ \\
& Village: Bandhabila Upazila:Bagarpara & HLQ & HLQ \\
\hline \multirow{3}{*}{ Rajshahi } & Village: Bashantapur Upazila: Godagari & PRA & HLQ \\
& Village: Duari, Upazila: Paba & HLQ & HLQ \\
& Village: Santoshpur, Upazila: Paba & HLQ & HLQ \\
\hline \multirow{3}{*}{ Jamalpur } & Village: Rayer Bakai, Upazila: Melandah & PRA & HLQ \\
& Village: Sthal, Upazila: Sarishabari & HLQ & HLQ \\
& Village: Norkona, Upazila: Muktagacha & HLQ & HLQ \\
\hline
\end{tabular}

Legends: PRA=Participatory rural appraisal, HLQ=Household level questionnaire

\section{Data analysis}

The data of base line information and impact assessment were compiled and analyzed in Excel. In some cases, data were converted into percentage and Chisquare test was done. Impacts were estimated by the difference from the data of base-line information and impact assessment survey.

\section{Results and Discussion}

\section{New variety adoption and varietal diversity}

Before starting PVS activity in 2002, 97.8\% wheat area was covered by Kanchan at the 12 PVS villages of Bangladesh. It was $100 \%$ at Dinajpur and Jamalpur, 98\% at Rajshahi, and 95\% at Jessore. Farmers' participation in the PVS research for three years, made them aware about the superiority of the new varieties over Kanchan in their own agro-economic and management conditions. As a result, they had significantly reduced the area of BpLB susceptible Kanchan variety, irrespective of districts. The average area of Kanchan in 2004-05 was 57\%. It was $62.3 \%$ at Jessore, $58 \%$ at Rajshahi, and $55 \%$ at Jamalpur (Table 2). The cultivated areas of new varieties were $43 \%$. This area was statistically similar to that of Kanchan in 2004-05. The cultivated areas of new varieties were $37.7 \%$ at Dinajpur, $49.5 \%$ at Jessore, $41 \%$ at Rajshahi, and $45 \%$ at Jamalpur districts. Among the six new varieties, the area of Shatabdi was the highest, because of farmers' higher preference to it and more availability of seeds. The area of 
Shatabdi was statistically similar to the area of new varieties in all districts except Jamalpur.

Table 2. Adoption status of new wheat varieties at the PVS villages of Bangladesh in 2004-05.

\begin{tabular}{|c|c|c|c|c|c|c|}
\hline \multirow[t]{2}{*}{ Year } & \multirow[t]{2}{*}{ Varieties } & \multicolumn{5}{|c|}{ Area in percent } \\
\hline & & Dinajpur & Jessore & Rajshahi & Jamalpur & Average \\
\hline \multirow{6}{*}{$2002-03$} & Kanchan & 100 & 95 & 98 & 100 & 97.8 \\
\hline & & $62.3 * *$ & $51.5 * *$ & $59.0 * *$ & $55.0 * *$ & $57.0 * *$ \\
\hline & Kanchan & $\chi^{2} \mathrm{P}=0.003 \S$ & $\chi^{2} \mathrm{P}=0.000 \S$ & $\chi^{2} \mathrm{P}=0.001 \S$ & $\chi^{2} \mathrm{P}=0.000 \S$ & $\chi^{2} \mathrm{P}=0.001 \S$ \\
\hline & Protiva & 2.1 & 2.1 & 5.0 & 5.0 & 3.6 \\
\hline & Shatabdi & $34.3 \mathrm{~ns} £$ & $43.8 \mathrm{~ns} £$ & $25.0^{*}$ & $31.5 \mathrm{~ns} £$ & $33.7 \mathrm{~ns} £$ \\
\hline & & & & $\chi^{2} \mathrm{P}=0.048 £$ & & \\
\hline \multirow[t]{6}{*}{ 2004-05 } & Sourav & 0.2 & 1.0 & 3.0 & 3.0 & 1.8 \\
\hline & Gourab & 0.7 & 1.0 & 5.0 & 2.0 & 2.2 \\
\hline & BAW 1006 & 0.2 & 0.1 & 1.4 & 2.0 & 0.9 \\
\hline & BAW 1008 & 0.3 & 0.2 & 1.6 & 1.5 & 0.9 \\
\hline & & $37.7 *$ & $49.5 \mathrm{~ns} \neq$ & $41.0 \mathrm{~ns} \neq$ & $45.0 \mathrm{~ns} \neq$ & $43.0 \mathrm{~ns} \neq$ \\
\hline & $\begin{array}{l}\text { All new } \\
\text { varietis }\end{array}$ & $\chi^{2} \mathrm{P}=0.013 \neq$ & & & & \\
\hline
\end{tabular}

$\S=$ Compared with the area of Kanchan in $2002 ; \neq=$ compared with the area of Kanchan in 2004-05 and $£=$ compared with the area of all new varieties.

The adoption of new varieties has increased the mean yield of wheat in the villages. The yield of new varieties was $820 \mathrm{~kg} / \mathrm{ha}$ higher than Kanchan. Wheat shortage in the country may reduce remarkably if the PVS approach can be widely used throughout the country. Withcombe (1999) reported that if participatory approaches could widely be applied, they would contribute greatly to the food security of the developing world with its rapidly growing populations.

The average cultivating area of Protiva was $3.6 \%$, Gourab $2.2 \%$, Sourav 1.8\% and BAW 1006 and BAW 1008 was 0.9\% each in 2004-05. Shatabdi, Sourav, and Gourab varieties were being demonstrated for several years throughout the country in conventional methods, but it could not made remarkable impact in replacement of Kanchan, but PVS approach was able to do that. Varietal diversity was also increased remarkably and seven varieties were grown in 2004-05. Joshi and Witcombe (1996) reported that adoption rates of cultivars would be improved by increased farmers' participation and poor farmers adopt new varieties as rapidly as wealthier ones through PVS. This approach again proved itself as a superior concept than the traditional one. Witcombe et al. (1996) stated that PVS was a more rapid and cost effective way of identifying farmers-preferred cultivars if a suitable choices of cultivars are supplied to test. Area expansion of new varieties was comparatively low due to limitations of seed. In the existing seed regulation of the country, there is a 
restriction of producing and distributing seeds of unreleased varieties. Farmers were fully motivated about new varieties and they had extreme demand for the seeds of BAW 1008 and BAW 1006. In 2005, those lines have been released as varieties by National Seed Board (NSB) and farmers have preserved 100\% seeds of those they harvested from PVS trials in 2004-05 to increase their areas in the next year.

\section{Seed production and preservation}

Seed is very important for extension of a variety. Bangladesh Agricultural Development Corporation (BADC), the only public seed sector of the country provides $15-20 \%$ seeds of the total requirement. So, providing training to the farmers for seed production and preservation was very important for higher yield. PVS activity has improved the knowledge of farmers in seed production and preservation. As a result, 208 tons seeds of new varieties were produced and preserved by the farmers of 12 PVS villages in 2004-05 (Table 3). The highest quantity seeds were produced and preserved at Dinajpur (123 tons) followed by Jessore (61.6 tons), Rajshahi (14.7 tons), and Jamalpur (8.8 tons). Among those, the quantity of Shatabdi seeds was the highest (183.4 tons) followed by Protiva (8.5 tons), BAW 1008 (5.6 tons), BAW 1006 (5.3 tons), Gourab (3.4 tons), and Sourav (2.0 tons). Good quantity source seeds and higher farmers' preference to the variety Shatabdi were the causes for production and preservation of more quantity of its seeds. Farmers' preference to BAW 1008 and BAW 1006 was also very high, but due to existing seed regulation, they could not produce and preserve seeds of unreleased varieties. However, some farmers confidentially preserved those seeds and that quantity was good enough for seed increase in next season. PVS helped the farmers getting rapid advantage from new varieties. Otherwise, reaching seeds of new varieties to the farmers in normal channel (through BADC) needs at least 5 years. By this time, many varieties start degenerating and ultimately farmers do not like those.

Table 3. Quantity of seeds of new varieties stored in PVS villages in 2004-05, Bangladesh.

\begin{tabular}{l|c|c|c|c|c|c}
\hline Sl\# & Variety & \multicolumn{5}{|c}{ Production (ton) } \\
\cline { 3 - 7 } & & Dinajpur & Jessore & Rajshahi & Jamalpur & Total \\
\hline 1 & Shatabdi & 110.0 & 56.9 & 10.9 & 5.7 & 183.4 \\
2 & Protiva & 6.8 & 0.5 & 0.8 & 0.5 & 8.5 \\
3 & Sourav & 0.5 & 0.4 & 1.1 & 0.2 & 2.0 \\
4 & Gourab & 2.3 & 0.3 & 0.5 & 0.3 & 3.4 \\
5 & BAW & 1.8 & 1.6 & 0.8 & 1.1 & 5.3 \\
6 & BAW1008 & 1.7 & 1.9 & 0.8 & 1.2 & 5.6 \\
\hline Total & & 123.0 & 61.6 & 14.7 & 8.8 & 208.1 \\
\hline
\end{tabular}


In 2002, most of the farmers of PVS villages did not preserve any wheat seeds due to lack of proper knowledge of preservation technique. BADC was the major source $(60 \%)$ of their wheat seeds followed by local market $(36 \%)$ and relatives (4\%). In 2005, seed source was completely changed. Farmers were trained several times about seed production and preservation techniques through PVS, and they learned those very efficiently. They also understood the importance of good quality seeds. Therefore, in 2004-05, farmers of the village used $100 \%$ seeds from their own source. In that season, $60 \%$ seeds were used from their own preservation, $30 \%$ from neighbours and only 10\% from their relatives (Fig. 1). This was a tremendous achievement of PVS activity. Many of these farmers were also trained many times before starting PVS in traditional ways but that could not bring any impact. Successful storing of seeds also benefited them financially. Many farmers earned good amount of money by selling seeds. Seeds of BAW 1008 and BAW 1006 were sold @ Tk. 40/kg and Shatabdi @ Tk. 30/kg, whereas, BADC sold seeds@ Tk. 22/kg. Some of the farmers became socially enlighten as because the high officials from Extension Department and BADC went to them and collected seeds of new varieties for distribution to other areas.

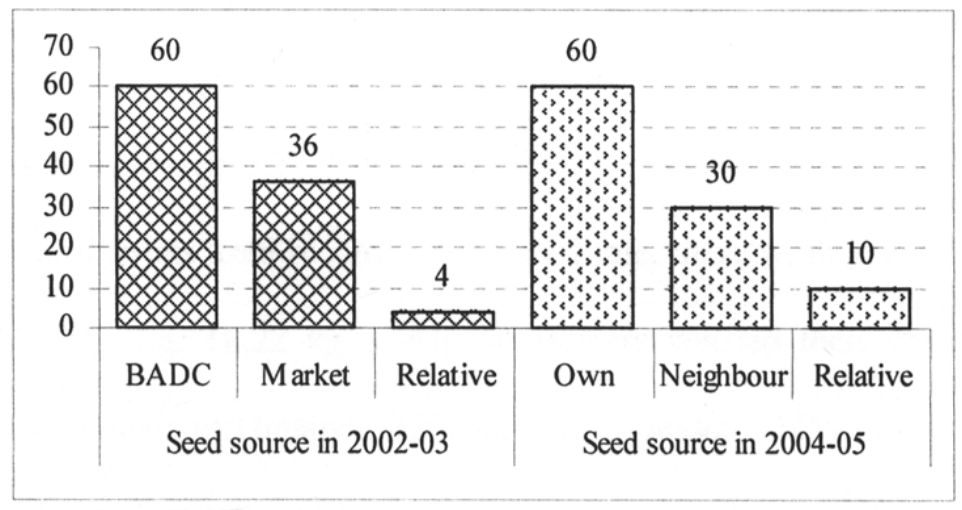

Fig. 1. Seed source change due to PVS activity in working villages of Dinajpur.

\section{New technology adoption}

Like new variety adoption, PVS activity helped remarkably in adoption of management technologies and that might be due to imparting training and doing frequent interactions with the farmers. The production technology adoption data presented in Table 4 indicated that at Dinajpur District $80 \%$ farmers had sown wheat in late before 2002, but in 2005, 61.1\% farmers' seeded in optimum time (15-30 November). At Jessore District, optimum seeding was increased from 10 to $75 \%$. In Rajshahi and Jamalpur districts that increase was from 30 to $84 \%$ and 20 to $34 \%$, respectively. That was very important for wheat yield increase in 
Bangladesh, because for each day delay seeding after 30 November (optimum time), wheat yield reduces @ 1.3\% i.e. 43 kg/ha (Saunders, 1988). Before 2002, farmers' used average seed rate of $200 \mathrm{~kg} / \mathrm{ha}$ (Baksh et al., 2003), whereas, recommended seed rate is $120 \mathrm{~kg}$. After three years of participatory research, $52 \%$ farmers of Dinajpur, 55\% of Jessore, $58 \%$ of Rajshahi, and $39 \%$ farmers of Jamalpur districts used recommended seed rate, thereby, they could save $80 \mathrm{~kg}$ seeds/ha which costs Tk. 1760 @ Tk. 22/kg. All the farmers weeded their crops manually upto 2002, but in 2005, 20.6\% farmers of Dinajpur, 33\% farmers of Jessore, $56 \%$ farmers of Rajshahi and $35.4 \%$ farmers of Jamalpur districts used herbicides (2-4-D Amine) to weed their wheat crop, thus, they could reduce their weeding costs. Before 2002, all wheat farmers irrespective of districts used 1-2 irrigations but in 2004-05, 22\% (Jamalpur) to 34\% farmers (Jessore) used three irrigations which enhanced yield. All farmers' sowed wheat by broadcasting before 2002 and in 2004-05, 5\% farmers in Rajshahi and 23\% farmers in Jessore seeded wheat in lines. As a result, they were able to reduce seed and weeding costs and also got higher wheat yield.

Table 4. Adoption of recommended production technologies in the PVS villages of Bangladesh.

\begin{tabular}{|c|c|c|c|c|}
\hline Technology & Dinajpur & Jessore & Rajshahi & Jamalpur \\
\hline Seeding & $\begin{array}{l}61.1 \% \text { optimum ( } 20 \% \\
\text { optimum) }\end{array}$ & $\begin{array}{l}75 \% \text { optimum ( } 10 \% \\
\text { optimum) }\end{array}$ & $\begin{array}{l}84 \% \text { optimum ( } 30 \% \\
\text { optimum) }\end{array}$ & $\begin{array}{l}34 \% \text { optimum ( } 20 \% \\
\text { opimum) }\end{array}$ \\
\hline Seed rate & $\begin{array}{l}52 \% \text { area recommended } \\
(120 \mathrm{~kg} / \mathrm{ha}) \text { (Average } \\
200 \mathrm{~kg})\end{array}$ & $\begin{array}{l}55 \% \text { area } \\
\text { recommended }(120 \mathrm{~kg} / \\
\text { ha) (Average } 200 \mathrm{~kg})\end{array}$ & $\begin{array}{l}58 \% \text { area } \\
\text { recommended }(120 \\
\mathrm{kg} / \mathrm{ha}) \text { (Average } \\
200 \mathrm{~kg})\end{array}$ & $\begin{array}{l}39 \% \text { area recommended } \\
(120 \mathrm{~kg} / \mathrm{ha} \text { ) (Average } \\
200 \mathrm{~kg})\end{array}$ \\
\hline Weeding & $\begin{array}{l}79.4 \% \text { manually, } 20.6 \% \\
\text { herbicide ( } 2-4 \text { D amine) } \\
\text { (100\% Manually) }\end{array}$ & $\begin{array}{l}67 \% \text { manually, } 33 \% \\
\text { herbicide }(2-4 \mathrm{D} \\
\text { amine) }(100 \% \\
\text { Manually) }\end{array}$ & $\begin{array}{l}44 \% \text { manually, } 56 \% \\
\text { herbicide }(2-4 \mathrm{D} \\
\text { amine) }(100 \% \\
\text { Manually) }\end{array}$ & $\begin{array}{l}65.5 \% \text { manually, } 34.5 \% \\
\text { herbicide ( } 2-4 \mathrm{D} \text { amine) } \\
\text { (100\% Manually) }\end{array}$ \\
\hline Irrigation & $\begin{array}{l}26 \%-3 \text { irrigations } \\
40 \%-2 \text { irrigations } 34 \%- \\
1 \text { irrigations ( } 100 \% 1-2 \\
\text { irrigation) }\end{array}$ & $\begin{array}{l}34 \%-3 \text { irrigations } \\
46 \%-2 \text { irrigations } \\
20 \%-1 \text { irrigation } \\
\text { (100\% } 1-2 \text { irrigation) }\end{array}$ & $\begin{array}{l}27 \%-3 \text { irrigations } \\
46 \%-2 \text { irrigations } \\
27 \%-1 \text { irrigation } \\
\text { (100\% } 1-2 \\
\text { irrigation) }\end{array}$ & $\begin{array}{l}22 \%-3 \text { irrigations } \\
39 \%-2 \text { irrigations } 39 \%-1 \\
\text { irrigation (100\% 1-2 } \\
\text { irrigations) }\end{array}$ \\
\hline Sowing & $\begin{array}{l}78.1 \% \text { broadcasting } \\
21.9 \% \text { line sowing } \\
(100 \% \text { broadcasting })\end{array}$ & $\begin{array}{l}77 \% \text { broadcasting } \\
23 \% \text { line sowing } \\
(100 \% \text { broadcasting })\end{array}$ & $\begin{array}{l}95 \% \text { broadcasting } \\
5 \% \text { line sowing } \\
(100 \% \text { broadcasting })\end{array}$ & $\begin{array}{l}14.9 \% \text { broadcasting } \\
15.1 \% \text { line sowing } \\
(100 \% \text { broadcasting })\end{array}$ \\
\hline
\end{tabular}

Figures and texts in the bottom line in each cell within parenthesis are the information before starting PVS activity in 2002.

\section{Sources of agricultural knowledge}

The farmers of Bangladesh get agricultural knowledge from different public and private organizations and personnel. Before 2002, farmers were getting 25\% information through demonstration followed by DAE personnel (24\%), others (relatives, seed dealer, input dealers, NGOs, etc.) (15\%), neighbours (14\%), 
research (12\%), and BADC (10\%). After three years of PVS activity, there was remarkable changes in information sources due to frequent visit and discussion of researchers and extension personnel with the farmers. DAE and research personnel were the most reliable sources of agricultural information. The contribution of these two sectors together was $36 \%$ in pre-PVS period. In the post-PVS period, their contribution significantly increased to $77 \%$. The contribution of other sectors was reduced remarkably due to PVS activity. This change has increased the possibility of getting appropriate technologies, because, other sectors, that were involved in technology transfer activities before PVS, were not appropriate authority (except seed by BADC) and in many cases, they might have no correct knowledge. This has also increased the possibility of increasing yield due to reliable technology use.

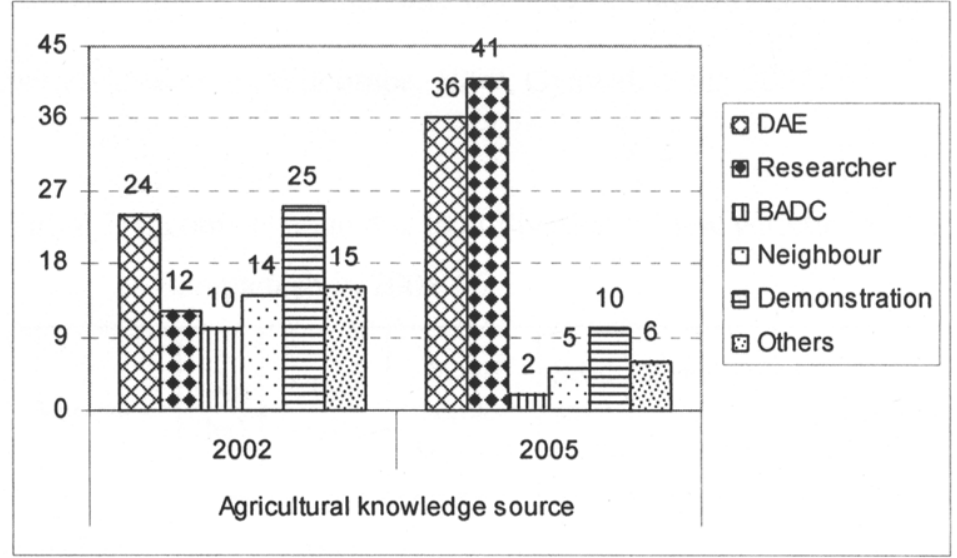

Fig. 2. Changes in source of agricultural knowledge to the farmers of Bangladesh due to participation in PVS.

\section{Income change}

Farmers of PVS villages have brought changes in their income participating in PVS research during 2002 to 2005. The data presented in Table 5 indicated that due to cultivation of modern wheat varieties and use of recommended production technologies, yield was increased remarkably. They were also able to save seeds using recommended seed rate. Average yield increases in the PVS villages of Bangladesh from new wheat varieties only and from all varieties together were 820 and $410 \mathrm{~kg} / \mathrm{ha}$ over Kanchan. So, total production increase was $127100 \mathrm{~kg}$ from new varieties (grew in $155 \mathrm{ha}$ ) and $154160 \mathrm{~kg}$ from all varieties (grew in 376 ha). So, price of that additional production from new varieties and all varieties were Tk. 1588750 and 1927000, respectively. Farmers of PVS villages used recommended seed rate in 51\% wheat areas and from that area they saved 
$80 \mathrm{~kg}$ seeds/ha. Therefore, they saved $6324(155 \times 51 / 100 \times 80) \mathrm{kg}$ and 15341 $(376 \times 51 / 100 \times 80) \mathrm{kg}$ seeds from areas of new varieties and total wheat areas, respectively (Table 5). The price of those saved seeds was 139128 (6324 x 22) and Tk. 337502 (15341 x 22), respectively. The farmers got total additional income from cultivation of new varieties only and using recommended seed rate was Tk. $1727878(1588750+139128)$ and from all varieties and recommended seed rate was Tk. $2264502(1927000+337502)$. So those farmers' who grew only new varieties got additional income of Tk. 11148 and those who grew all varieties got additional income of Tk. 6023/ha over Kanchan. A financial analysis revealed that a very high internal rate of return is possible to get from investment in participatory variety selection (Witcombe, 1999; Grawali et al., 2002).

Table 5. Income change due to cultivation of new varieties and saving seeds at the PVS villages of Bangladesh in 2004-05.

\begin{tabular}{|c|c|c|c|c|c|c|c|c|c|}
\hline \multirow[t]{2}{*}{ Varieties } & \multirow{2}{*}{$\begin{array}{l}\text { Area } \\
\text { (ha) }\end{array}$} & \multirow{2}{*}{$\begin{array}{l}\text { Yield } \\
(\mathrm{kg} / \mathrm{h} \\
\text { a) }\end{array}$} & \multirow{2}{*}{$\begin{array}{l}\text { Yield } \\
\text { increase } \\
\text { (kg/ha) }\end{array}$} & \multirow{2}{*}{$\begin{array}{l}\text { Seed } \\
\text { save } \\
(\mathrm{kg} / \mathrm{ha})\end{array}$} & \multirow[b]{2}{*}{$\begin{array}{l}\text { Seed } \\
\text { saved } \\
\text { in } 51 \% \\
\text { areas } \\
(\mathrm{kg})\end{array}$} & \multicolumn{2}{|c|}{ Price of } & \multirow[b]{2}{*}{$\begin{array}{l}\text { Total } \\
\text { additio } \\
\text { nal } \\
\text { income } \\
\text { (Tk.) }\end{array}$} & \multirow[b]{2}{*}{$\begin{array}{l}\text { Addition } \\
\text { al. } \\
\text { income } \\
\text { (Tik./ha) }\end{array}$} \\
\hline & & & & & & $\begin{array}{l}\text { additio } \\
\text { nal } \\
\text { yield } \\
\text { (Tk.) }\end{array}$ & $\begin{array}{l}\text { saved } \\
\text { seeds } \\
\text { (Tk.) }\end{array}$ & & \\
\hline Kanchan & 221 & 2065 & -- & & -- & -- & -- & -- & -- \\
\hline $\begin{array}{l}\text { New } \\
\text { varieties }\end{array}$ & 155 & 2885 & 820 & 80 & 6324 & 1588750 & 139128 & 1727878 & 11148 \\
\hline All varieties & 376 & 2475 & 410 & & 15341 & 1927000 & 337502 & 2264502 & 6023 \\
\hline
\end{tabular}

Price of $1 \mathrm{~kg}$ grain $=\mathrm{Tk} .12 .5$ and $1 \mathrm{~kg}$ seed $=\mathrm{Tk} .22$

\section{Attitude change}

PVS activity has changed the attitudes of the farmers, researchers, extension and NGO personnel, and policy makers of Wheat Research Centre, BARI. During PVS activity, lots of interactions were made with the farmers by the researchers, extension and NGO personnal and a good number of trainings were imparted to them. As a result, their attitudes about researchers and extension personnel were changed remarkably. Their attitudes about new varieties and recommended technologies were also changed. Farmers had variable reactions about researches and extension personnel in pre PVS period. However, after participation in PVS research for three years, $100 \%$ of 360 farmers of different socio-economic groups stated that their reliability to researches and extension personnel was increased (Fig. 3). All farmers showed their interest to grow new wheat varieties, they preferred during their selection, and $89 \%$ farmers showed interest to use recommended production technologies. Eighty eight percent farmers stated that their interest to go to extension office for agricultural advice has increased in last 
three years and $95 \%$ farmers told that their interest has increased to continue cultivation of new varieties and use of recommended production technologies. Scientists of other disciplines are also thinking to initiate participatory research with their technologies. WRC, BARI has already institutionalized PVS research and continuing that from 2005 by Government budget. Atlin et al., 2002 has also emphasized on institutionalization of the PVS approach for getting long term sustainable advantage of the system. Farmer-selected 2 genotypes BAW 1006 and BAW 1008 have been released in 2005. They yield and farmers preference data of PVS experiments were also supplied to the National Technical Committee (NTC) of National Seed Board in addition to NSB requisite information. Those data helped greatly to rapid release the lines as varieties. Many of the members of NTC appreciated those data.

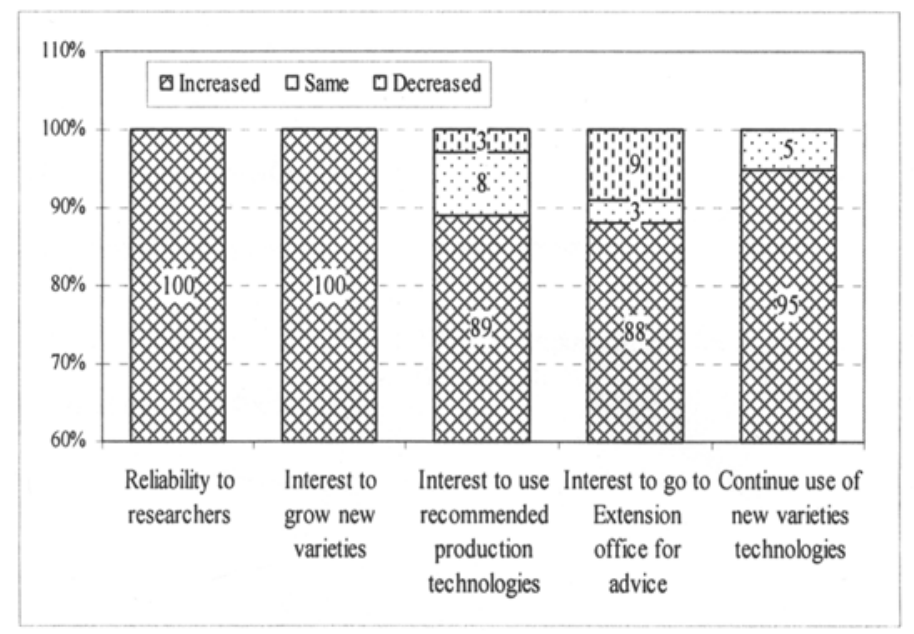

Fig. 3. Attitude change of the farmers due to PVS research in Bangladesh.

\section{Women empowerment}

In the impact assessment interview, 20 female farmers were involved in three villages of Dinajpur District. All of them replied that their knowledge on agricultural activity was increased in last three years due to interaction with the researchers. Directorate of Agricultural Extension (DAE) and NGO personnel. Seventy five percent female farmers replied that their decision-making capacity in the family had increased. The rest $25 \%$ stated that their decision making power in the family remained the same as it was three years before (Fig. 4). 


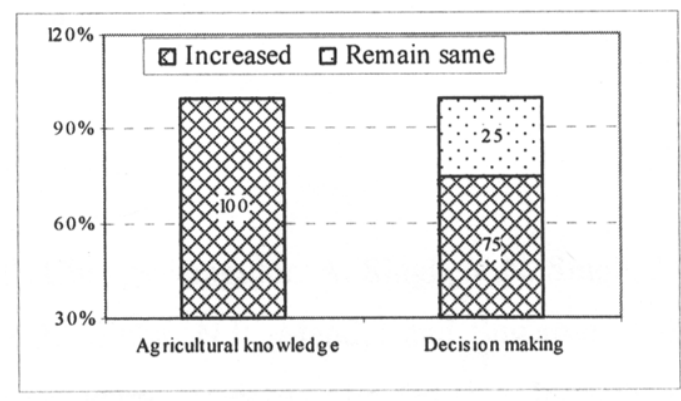

Fig. 4. Women empowerment due to PVS in Bangladesh.

\section{Conclusion}

Participatory variety selection research reduced the area of Kanchan from $97.8 \%$ to $57 \%$ by 3 years. Varietal diversity was increased and seven varieies were found to grow in $43 \%$ wheat areas of the working villages in 2004-05. Due to imparting training and doing lot of interactions with the farmers during three years of project period; their knowledge on seed preservation was improved. As a result, farmers preserved their own seeds rather than dependence on BADC and other sources. They adopted recommended management technologies to a considerable extent. Their sources of agricultural knowledge were changed remarkably and most of the farmers were dependent on research and extensionthe most reliable information source. Due to adoption of new varieties and management technologies, average yield of the villages was increased notably, as a result, their income was increased remarkably. The attitudes of the farmers were also changed about PVS, researchers, and extension personnel.

\section{Acknowledgements}

The authors are grateful to Dr. G.O. Ferrara, Dr. J.R. Witcombe, Dr. D.S. Virk, and Dr. K. D. Joshi for providing funds and giving suggestions and guidelines in conducting the research during the whole project period. The authors would like to thank all the participating farmers and extension officials of greater Dinajpur, Jessore, Rajshahi, and Jamalpur districts of Bangladesh for their cooperation in conducting the research and collecting the data.

\section{References}

Atlin, G.N., T.R. Paris, B. linquest, S. Phengchang, K. Chongyikangutor, A. Singh, V.N. Singh, J.L. Dwibedi, S. Pandey, P. Cenas, M. Laza, P.K. Sinha, N.P. Mandal and Suwarno. 2002. Integrating conventional and participatory crop improvement in rain fed rice. In breeding rain fed rice for drought-prone environments: integrating conventional and participatory plant breeding in south and south-east Asia. Eds. 
Witcombe, J.R, Parr, L.B and Atlin, G.N. Proc. of DFID Pl. Sci. Res. Prog/IRRI Conference. 12-15 March 2002, IRRI, Los Banos, Philippines, pp. 39.

Baksh, E., M.H. Rashid and M.G. Rabbani. 2003. Participatory rural appraisal of PVS site Daulatpur, Thankurgaon, Dinajpur, Bangladesh. A PRA report of Wheat Research Centre, Bangladesh Agricultural Reseach Institute, Nashipur, Dinajpur, pp. 31.

Grisley, W. and M. Shamambo. 1993. An analysis of adoption and diffusion of Carioca beans in Zambia resulting from an experimental distribution of seed. Experimental Agriculture 29:379-386.

Gyawali, S., K.D. Joshi and J.R. Witcombe. 2002. Participatory plant breeding in rice in low-altitude production systems in Nepal. Proceedings of a DFID-Plant Science Research Programme (PSP), Cenre for Arid Zone Studies (CAZS)/IRRI conference, 12-15 March 2002, IRRI, Los Banos, Laguna, Philippines. pp. 8-10.

Joshi, K.D., R.B. Rana, M. Subedi, K.B. Kadayat and B.R. Sthapit. 1995. Effctiveness of participatory testing and dissemination programme: a case study of Chaite Rice in the western hills of Nepal. LARC working paper No. 95/49. Pokhara, Nepal: lumble Agricultural Research Centre.

Joshi, A and J.R. Witcombe. 1996. Farmer participatory crop improvement. II. Participatory Varietal Selection. a case study in India. Expl. Agric. 32: 461-477.

Saunders, D.A. 1988. Crop Management Research Summery of Results, 1983-88. Monograph No. 5. Wheat Research Centre, Bangladesh Agricultural Research Institutes. Joydebpur, Gazipur.

Spearling, L and M.E. Loevinsohn. 1993. The dynamics of adoption: distribution and morality of bean varieties among small farmers in Rwanda. Agricultural Systems 41:441-453.

Sufian, M.A. 2005. Sustainable wheat production in Bangladesh in relation to climate change. A Key note paper presented at the workshop on "Sustainable Wheat Production, held at BRAC Centre Inn, Dhaka on October 2005.

Witcombe, J.R., A. Joshi, K.D Joshi, and B.R. Sthapit. 1996. Farmers participatory crop improvement. I. varietal selection and breeding methods and their impacts on biodiversity. Experimental Agriculture 32: 445-460.

Witcombe, J.R. 1999. Do farmer participatory methods apply more to high potential areas than to marginal ones? Outlook on Agriculture 28:43-49. 